but applications had to be considered first and foremost on their scientific merits and in relation to the balance of support the Department was affording to those fields of science for which it was responsible. For the major research project scientific considerations were paramount. The Nuclear Physics SubCommittee at the end of 1960 had recommended to the Research Grants Committee that Prof. Dee's project should be supported in principle, and Prof. Dee had been informed that it was open to him to re-submit his application, either for this or for a similar machine, in future years although it was most unlikely that the Department would be in a position to support before the financial year 1964-65 any further major projects other than those already announced.

\section{Cost of Power Production by Nuclear Energy in Britain}

In reply to questions in the House of Commons on February 19, the Minister of Power, Mr. R. Wood, said that the estimate for base load generation from the Bradwell and Berkeley nuclear power stations, which come into service in the next few months, was 1d. a unit, compared with $0.55 d .-0 \cdot 7 d$. from coal-fired stations coming into service this year, depending on their size and distance from the coalfields. The present estimate for Sizewell, due to come into service during 1965-66, was $0.65 d$, compared with $0.5 d$.$0.65 d$. for coal-fired stations commissioned at the same time. The capital cost per kilowatt at Bradwell and Berkeley was $£ 165$ and at Sizewell it would be down to $£ 100$. The expectation now was that nuclear generation would break even with coal-fired generation about 1970 .

\section{British Expenditure on Space Research}

In a written answer in the House of Commons on February 19, the Parliamentary Secretary for Science, Mr. D. Freeth, gave Government expenditure directly attributable to space research, excluding capital expenditure, as noarly $£ 300,000$ in $1960-61$, and estimated to rise to $£ 550,000$ in 1961-62. Government expenditure for 'civil' purposes on Blue Streak as a satellite launcher amounted to $£ 2 \cdot 6$ million in $1960-61$ and to some $£ 3.5$ million in 1961-62, apart from some expenditure since 1955 on military account.

\title{
MINING GEOPHYSICS IN SCANDINAVIA
}

$\mathrm{T}$ HE third Nordic Meeting for Mining Geophysicists was held in Helsinki during November $27-29,1961$. Four delegates from Denmark, 38 from Finland, 12 from Norway and 16 from Sweden, 70 persons altogether, participated in the meeting. Apart from geophysicists, there were also geologists and technicians among those present. The sessions were presided over by Dr. David Malmqvist from Boliden, Sweden, chairman of the organizing committee.

The programmo included 19 lectures, covering different branches of applied geophysics such as magnetic, electrical, gravimetric and seismic investigations, case-histories, use of computing machines, teaching of applied geophysics, etc.

S. Werner's paper dealt with the aeromagnetic methods used by the Geological Survey of Sweden. The flights were usually made at a flight elevation of $30 \mathrm{~m}$., with a spacing of traverses of $200 \mathrm{~m}$. Digital recorders were used for the registering which was synchronized with the flight speed. The handling of results and the drawing of aeromagnetic maps had been mechanized and rationalized so far as possible in order that they could be managed by a small personnel. A. Metzger (Finland) gave an account of the magnetic, electric and seismic methods used by the Pargas Kalkberg Co., with special reference to inductive depth determinations (Haalck-Metzger and Stefanescu's loop methods). A. Breen (Norway) gave a general survey of the development in geophysical prospecting in Norway during recent years.

H. Braekken (Norway) presented three papers. The first dealt with education in applied geophysics. In Scandinavian universities and technical high schools, very little provision is at present made for applied geophysics. The situation could be improved by means of more efficient international co-operation. The second paper concerned potential small-scale model experiments made by the author. In his third paper Mr. Braekken discussed the general problems concerned with the preparation and interpretation of geophysical maps. He pointed out that on such maps the measurements should be given so that the essential facts are clearly apparent at first glance.

J. Nuutilainen (Finland) and A. Levanto (Finland) described the magnetic surveys of the Kärväsvaara iron ore carried out by the Otanmäki Co. The magnetic field from the Kärväsvaara ore had been outlined using detailed measurements (taken with a 3-component Otanmäki Co. magnetometer) at groundlevel and in drill holes. The problems of the mathematical interpretation of magnetic anomalies were discussed. The main emphasis was laid on the errors made and found. B. Karlemo (Sweden) gave an account of a terrain correction method using an electronic computing machine as carried out by the Geological Survey of Sweden.

T. Eriksson (Sweden) gave a lecture on the interpretations of the aeromagnetic anomalies observed in the Sitasjaure area which had been made on the basis of a combination of geophysical and geological ground-level investigations. The investigations showed that the geological structure of the area was more complicated-for example, the faulting was more extensive than was at first thought to be the case.

M. Puranen (Finland) gave an account of the geophysical investigations carried out in the Jotnian sandstone formation in Satakunta by the Geological Survey of Finland. The seismic reflexion measurements carried out in the area and interpretations of the aeromagnetic anomaly curves showed that the thickness of the sandstone layer was $1,200-1,500 \mathrm{~m}$.

M. Laurila (Finland) gave an account of the airborne magnetic and electromagnetic surveys and the ground investigations carried out by the Outokumpu Co., which led to the discovery of the Kalliokylä ore-body in Kiuruvesi, Central Finland. Mr. T. Siikarla (Finland) described the magnetic and gravimetric research carried out by the Geological Survey of Finland, which resulted in large findings 
of chromite at Kemi. This non-magnetic chromite ore, which is heavier than its surroundings, is associated with an anorthosite-serpentinito intrusion. It was possible to make both magnetic and gravimetric measurements for locating the ore-body, and residual gravity maps proved especially useful.

L. Granar (Sweden) explained a new compensation method developed by the Geological Survey of Swoden, and the apparatus for measuring the potential field around an oro-body which is charged by a commutated direct current. The apparatus is also suitable for conventional resistivity detorminations by means of direct current. A lecturo by $O$. Lindholm (Finland) dealt with magnetic permeability measurements at the Otanmäki mine. The Otanmäk Co. had developed a method and apparatus for carrying out permeability determinations in drill holes. Thus, information about the location and quality of the ore could be procured cheaply and quickly by means of magnetic measurements. During the period $1956-61$ a total length of $130 \mathrm{~km}$. of drill hole was investigated by this method in the Otanmäki mine. P. Singsaas (Norway) gave an account of the electromagnetic conductive measurements which had been usod in research into zinc-lead oro deposits in Mofjollot, Nordland fylko. During the survey electrical anomalies were observed, which suggested that the ore-body continued at least one thousand metres eastwards from the mine. This result was later confirmed by diamond drilling.

P. Taanila and T. Kangas (Finland) gave an account of the seismic depth-to-bedrock determinations by refraction methods carried out by the Oulujoki Co. 'The Oulujoki Co. had developed a new profilo interpretation method and a special slido-rule which makes it possible to do the practical calculations rapidly. In his talk, J. Huhta (Finland) establishod that a hammer seismograph, developed by Goophysical Specialities Co., in the United States, had been used with great success in Kolari, North Finland, for determination of depth of shallow surface layers.
Associated with the meeting was an exhibition of instruments in which $\mathrm{H}$. Jalander (Finland) presented the latest model of his electronic magnetometer, L. A. Levanto Co., Finland, presented a gradient magnetometer developed by them, and the Otanmäki Co., Finland, showed their magnetic measuring devices for measuremonts of drill holes.

At the business meeting different ways of improving inter-Scandinavian co-operation for developing prospecting methods were discussed. The meeting decided that the organizing committeo of the third Geophysicist's Conference should continue its work, changing its name to "The Planning Committee", and that its task would be to examine tho possibilities of founding a new Scandinavian organization, as well as the possibilities of publishing the lectures held at the Helsinki meeting in English. The members of the planning committee were Messrs. Malmqvist (chairman), Braekken, Puranen and Saxov.

The Geophysics Education Committee, appointed by the second Nordic Meeting for Mining Geophysicists, decided to continue its work, and, furthermore, various sections would deal with technical mapping probloms, the question of nomenclature, a Scandinavian gravimotric map, and scale-model oxperiments.

It was decided that the fourth Nordic Meeting for Mining Geophysicists would be held in approximately two years time, and A. Eriksen (Norway) was elected chairman of the organizing committeo, the members of which are Messrs. A. Breen (Norway), D. Malm. qvist (Swedon) and T. Siikarla (Finland).

The third Nordic Meeting for Mining Geophysicists was most successful, and the number of participants was much greater than at the two previous meetings, and also there was a large number of lectures. That these meetings serve their purpose, and that the interest in them is constantly growing among ore prospectors is obvious. The decisions mado by the meoting will do much to improve Scandinavian co-operation in the field of mining geophysics.

Maunu Puranen

\section{MECHANISM OF GLASS POLISHING}

$\mathrm{A}$ BIBLIOGRAPHY has been published recently by tho British Scientific Instrument Research Association on the subject of the polishing of glass*. The bibliography is the first product of a new programme of research on this topic. Although the first investigations of this subject go back some hundreds of years, it is one of great industrial importaneo in both the optical and the plate glass industries. 'The new 'float' glass process removes the nood for polishing and is a successful but courageons and expensive development; in tho United States important progross seoms to havo been made by 'chemical' polishing. This process involves the introduction of materials such us potassium fluoride into tho polishing slurry and has been claimed to reduce the polishing time by a factor of ten. In spite of these new developments, a fresh investigation in the difficult ficld is to be wolcomed.

For many years polishing was regarded as a microgrinding process in which glass was removed by a

* British Scientine Instrument Research Association. B.S.I.R.A. Recearch Report $R, 267$ : The Mechanisms of Glass Polishing-a History and 13íbliography. By Dr. D. C. Cornish. Pp. iv +70 (Chislehurst. Kent: British Scientific Instrument Research Associa tion, 1961.) pulling or cutting action of the polishing grains on a scale too small to reveal itself in the microscope. At the beginning of this century the idea was introduced of a plastic doformation of the surface with glass being removed from high spots to fill hollows; a similar suggostion was that undor the high local pressures set up in the polishing process, tomperatures werc reached locally at which the glass became molten. In the nineteen-thirties the possibility of chomical reaction playing a part bogan to find favour. F. W. Preston, for example, stressed the importance of reactions betwoen the glass and the water usod in polishing. A book published in the U.S.S.R. in 1946 recorded a large volume of work on the ion-exchange reaction between the surface of the glass and the polishing slurry. Two of the latost references in tho bibliography show that the Association is already actively engaged experimentally on this phase of the subject.

Iike other apparently simple industrial arts, the polishing of glass is a very complex phenomenon which still demands very caroful scientific work for its elucidation.

R. W, DOUGLAS 